\title{
Junto aos rios da Babilônia Um estudo acerca da história de Israel no exílio
}

\author{
Orientador: Prof ${ }^{a}$ Maria de Lourdes Corrêa Lima \\ Pesquisadora: Michel Alves dos Santos \\ Projeto de Pesquisa: Exegese Bíblica: Intertextualidade e Teologia \\ Fonte: $\mathrm{CNPq}$
}

A pesquisa se propôs realizar um estudo acerca da situação real dos deportados de Judá na Babilônia, buscando compreender o que foi o exílio tanto na perspectiva da abordagem histórica quanto na percepção subjetiva dos deportados. Neste sentido, o trabalho procurou estabelecer um diálogo entre as fontes bíblicas e os dados apresentados pelos historiadores acerca da Babilônia e, deste modo, compreender até que ponto a Bíblia e os fatos narrados nela durante este período são seguros para uma apreciação objetiva da história de Israel e da Babilônia no momento histórico em questão.

A pesquisa afasta o lugar comum de pensar o exílio babilônio como algo análogo à escravidão de que os hebreus foram vítimas no Egito. $\mathrm{O}$ estudo demonstrou que os exilados de Judá gozavam de liberdades comuns aos cidadãos babilônios. Tinham liberdade de culto. Podiam organizar-se comunitariamente. Não eram escravizados. O único fato que lhes limitava a liberdade era a ausência do direito de retornarem à sua pátria. Neste sentido, os escritos bíblicos deste período trazem mais um retrato do ânimo do povo exilado que a sua real situação.

Enfim, é preciso não subestimar o papel do cativeiro de Babilônia. A ele deveu Israel, em todos os domínios, essa profunda reflexão sobre si e um processo de espiritualização que foi o responsável pela formação do judaísmo e deixou marcas que aparecem ao longo de toda Sagrada Escritura. 